\title{
Technical analysis of 2007 and 2017 World Taekwondo Women and Men championship finals
}

\author{
Sevde MAVİ VAR \\ Kirsehir Ahi Evran Universtiy, School of Physical Education and Sports, Kirsehir ,Turkey \\ Address Correspondence to S,Var, e-mail: sevde.mavivar@ahievran.edu.tr
}

\begin{abstract}
Purpose of this study is to compare the latest world championships with the old system and the latest world championship competitions with the new system, and to compare the competitions in two different systems by conducting activity and technical analysis. Thus, the technical analysis of the 2007 and 2017 world taekwondo championship women's and men's finals was performed. SPSS 22.0 package program was used for statistical analysis of the acquired data and results were evaluated at p $<0.05$ significance level. Mann - Whitney U Test was applied to the techniques used (punch, palding, pusachagi, yopchagi, dwichagi, neryochagi, dollyochagi, pandedollyo), total technical numbers, frequency and percentage analysis of points and penalties and pairwise comparisons. When the findings of the study were examined, there were statistically meaningful differences found between the number of techniques used in the competition and the techniques used in the competitions in 2017 (women; $\mathrm{p}=.001$, men; $\mathrm{p}=.001$ ). In the world championship finals in 2007, while women athletes used a total of 404 techniques, they used 1152 techniques in the world championship finals in 2017. In 2007, totally 525 techniques were used in men and in 2017, 1205 techniques were used. As a conclusion, in Taekwondo, when the competitions between the old system and the new system are compared, it can be said that in the new system, the athletes use much more techniques and their scores increase considerably depending on the changing rules and the technical numbers.-
\end{abstract}

Keywords: Match Analysis, Performance Analysis, Taekwondo

\section{INTRODUCTION}

South Korea's old martial art taekwondo sport was officially taken into the Olympiads in 2000 and became a modern combat sport. Although taekwondo's fighting (kyorugi) and show (poomsae) competitions are organized regularly at regional, national and international levels; only the fighting (kyorugi) branch included in olympiads $(17,20)$. Taekwondo competitions are held in the form of a quarter-final, semi-final and final in the same day. Each event is made in 3 rounds from two minutes each (22).

The strength of the lower extremity in taekwondo is very important in order to apply effective techniques and to demonstrate successful performance. The power output and the ability to maintain this strength in the lower extremity eccentric and concentric muscle contractions are an important factor in providing support for technical and tactical applications in combat (4). Winning a competition in taekwondo not only the physical suitability and anthropometric structures activities but also the techniques, number of motional actions ratio and effectiveness play an important role (8).
Tall athletes in taekwondo can biomechanically take advantage of their short competitors. Taller athletes have longer upper and lower extremities, so they can shift to an advantageous position by taking up more space with less energy (10).

As in all sports branches, in taekwondo, the competition period is an important period in order to get the results of the studies carried out in preparation period, to reach its goals and to show superior performance. In this period, it is very important to record the competitions and to make the correct evaluations, to determine the athlete's situation, to see the mistakes of the athletes, to see the good sides and to make technical and tactical studies in accordance with these results.

Sports competitions after the preparation period are very important assessment areas for athletes and coaches. In this way, the effects of the preparatory period can be evaluated according to the results of the sport competition (9). Competition analysis, technical or technical activities in sports competitions in order to evaluate the performances 
of athletes in individual or team sports. There are important tools aimed at gathering information about situations (6). In order to improve the performances of the athletes, feedback after the matches and matches are effective results in the performance of the athlete (15).

In order to conduct competition analysis, the coaches do not need to participate directly in the analysis process or competition record system. However, in order to be able to make analysis, it is so important to have the ability to understand and correctly evaluate the analysis system (2). Trainers can combine their knowledge and thoughts with the knowledge that they get from competition analyses and they can evaluate the performance of their sportsmen or the team and do tactical studies (16).

In the taekwondo, the competitions were held by manual system before 2008. In the manual system, the opponent's body protector (safeguard) and the effective techniques to the head area were made by the referees subjectively (18). Since 2008, the World Taekwondo Federation and the European Taekwondo Federation have started to develop electronic systems and these new electronic systems have been implemented in the competitions (11). These days, competitions are made by electronic system for more objective and fair competitions. Yet, with the new enhancing systems there are differences seen in the physical, technical and tactical applications of the athletes.

For this reason, the aim of this study is to compare the competitions in two different systems by making the latest world championships with the new system which is the old system, and the latest world championship competitions made with the electronic system.

\section{MATERIAL \& METHOD}

In this study, the male and female finals of the 2007 and 2017 World Taekwondo Championships are based on the information obtained from the World Taekwondo Federation website; It was downloaded from Youtube and Dartfish Channel channels and monitored. In order to analyze the final competitions, the Taekwondo competition analysis form of Var et al. (2015) was used (13).

Table 1 points out the male and female athletes in all categories playing the final in the 2007 and 2017 World Championships. SPSS 22.0 package program was used for statistical analysis of the obtained data and results were evaluated at $p<0.05$ significance level. The techniques used (punch, palding, pusachagi, yopchagi, dwitchagi, neryochagi, dollyochagi, pandedollyo), total technical numbers, frequency and percentage analyzes of the points and penalties received were made (Table 2, Table 3, Table 4 and Table 5). The normality test was applied to determine if the data were in accordance with normal distribution. The 2007 and 2017 World Taekwondo Championships examined in the study the number of male athletes $(\mathrm{n}=16)$ and the female athletes $(\mathrm{n}=16)$ were 32 . Since the number of athletes of different years (32) was over 30, Kolmogorov-Smirnov table was considered. According to Kolmogorov-Smirnov table; since the variables are $(\mathrm{p}<0.05)$, they were not normally distributed. Therefore, nonparametric tests were applied to the variances. Mann Tablo Whitney U Test (Table 6 and Table 7) was applied for paired comparisons.

\section{RESULTS}

Table 1. 2007 and 2017 World Championship men and women finalists

\begin{tabular}{llll}
\hline $\mathbf{2 0 0 7}$ male & 2017 male & $\mathbf{2 0 0 7}$ female & $\mathbf{2 0 1 7}$ female \\
\hline $54 \mathrm{~kg}$ (Thailand-Korea) & $54 \mathrm{~kg}$ (Korea-Iran) & $47 \mathrm{~kg}$ (China-Thailand) & $46 \mathrm{~kg}$ (Korea-Vietnam) \\
\hline $58 \mathrm{~kg}$ (Mexico-Spain) & $58 \mathrm{~kg}$ (Korea-Russia) & $51 \mathrm{~kg}$ (Spain-Croatia) & $49 \mathrm{~kg}$ (Thailand-Serbia) \\
\hline $62 \mathrm{~kg}$ (Korea-Thailand) & $63 \mathrm{~kg}$ (China-Iran) & $55 \mathrm{~kg}$ (Taiwan-Korea) & $53 \mathrm{~kg}$ (Turkey-Russia) \\
\hline $67 \mathrm{~kg}$ (Iran-Cuba) & $68 \mathrm{~kg}$ (Korea-Taiwan) & $59 \mathrm{~kg}$ (Turkey-Korea) & $57 \mathrm{~kg}$ (Korea-Turkey) \\
\hline $72 \mathrm{~kg}$ (China-Afghanistan) & $74 \mathrm{~kg}$ (Russia-Uzbekistan) & $63 \mathrm{~kg}$ (Canada-Korea) & $62 \mathrm{~kg}$ (Ivory coast-Iran) \\
\hline $78 \mathrm{~kg}$ (USA-Korea) & $80 \mathrm{~kg}$ (Russia-Azerbaijan) & $67 \mathrm{~kg}$ (Korea-France) & $67 \mathrm{~kg}$ (Turkey-USA) \\
\hline $84 \mathrm{~kg}$ (Turkey-Azerbaijan) & $87 \mathrm{~kg}$ (Russia-Germany) & $72 \mathrm{~kg}$ (Korea-Mexico) & $73 \mathrm{~kg}$ (Korea-Serbia) \\
\hline$+84 \mathrm{~kg}$ (Mali-Iran) & $+87 \mathrm{~kg}$ (Nigeria-England) & $+72 \mathrm{~kg}$ (China-Korea) & $+73 \mathrm{~kg}$ (England-USA) \\
\hline
\end{tabular}

In Table 1, the 2007 and 2017 World Taekwondo Championships indicate the countries competing in the final competitions in the categories of men and women by category. Turkey in 2007 found that only Championships held in 2017 could not take place in the final competition in any weight class. In women who found the final match in Turkey in 2007, $59 \mathrm{~kg}$, $53 \mathrm{~kg}$ and $67 \mathrm{~kg}$ in 2017, it is determined that in the 
final competition. In Korea, women and men are

competitions in 2007 and 2017.

considered as the ones taking part in the final

Table 2. The frequency and percentage values of the techniques used in the men weights in the 2007 World

Championships finals

\begin{tabular}{lcccccccccccccccccc}
\hline Weigths & 54 & $\mathrm{~kg}$ & \multicolumn{2}{c}{$58 \mathrm{~kg}$} & \multicolumn{2}{c}{$62 \mathrm{~kg}$} & \multicolumn{2}{c}{$67 \mathrm{~kg}$} & \multicolumn{2}{c}{$72 \mathrm{~kg}$} & \multicolumn{2}{c}{$78 \mathrm{~kg}$} & \multicolumn{2}{c}{$84 \mathrm{~kg}$} & \multicolumn{1}{c}{$+84 \mathrm{~kg}$} & TOTAL \\
\hline Techniques & $\mathrm{f}$ & $\%$ & $\mathrm{f}$ & $\%$ & $\mathrm{f}$ & $\%$ & $\mathrm{f}$ & $\%$ & $\mathrm{f}$ & $\%$ & $\mathrm{f}$ & $\%$ & $\mathrm{f}$ & $\%$ & $\mathrm{f}$ & $\%$ & $\mathrm{f}$ & $\%$ \\
\hline Punch & 3 & 5 & 6 & 8 & 0 & 0 & 0 & 0 & 1 & 2 & 6 & 9 & 2 & 6 & 0 & 0 & 48 & 9 \\
\hline Paldıng & 8 & 85 & 63 & 84 & 105 & 86 & 53 & 91 & 49 & 85 & 50 & 68 & 28 & 80 & 20 & 100 & 416 & 79 \\
\hline Pusachagi & 1 & 2 & 0 & 0 & 3 & 2,5 & 1 & 2 & 1 & 2 & 0 & 0 & 0 & 0 & 0 & 0 & 6 & 1,5 \\
\hline Yopchagi & 0 & 0 & 0 & 0 & 0 & 0 & 0 & 0 & 0 & 0 & 15 & 20 & 0 & 0 & 0 & 0 & 15 & 3 \\
\hline Dollyochagi & 1 & 2 & 2 & 3 & 3 & 2,5 & 2 & 3,5 & 1 & 2 & 0 & 0 & 4 & 11 & 0 & 0 & 13 & 2 \\
\hline Neryochagi & 1 & 2 & 3 & 4,5 & 5 & 4 & 2 & 3,5 & 2 & 3,5 & 2 & 3,5 & 0 & 0 & 0 & 0 & 15 & 3 \\
\hline Dwitchagi & 2 & 4 & 1 & 1 & 6 & 5 & 0 & 0 & 1 & 2 & 0 & 0 & 1 & 3 & 0 & 0 & 11 & 2 \\
\hline Pandedollyo & 0 & 0 & 0 & 0 & 0 & 0 & 0 & 0 & 1 & 2 & 0 & 0 & 0 & 0 & 0 & 0 & 1 & 0,5 \\
\hline
\end{tabular}

Table 2 shows the percentage and frequency values of the techniques used in men's gears in the 2007 World Championship finals. When Table 2 is examined, it was observed that the athletes used palding technique with a rate of $79 \%(f=416)$. The least used technique is pandedollyo as $0.5 \%(f=1)$.
When it is considered in aspects of weight, it was observed that palding technique was used as $86 \%$ (f $=105)$ in $62 \mathrm{~kg}$ and at least $85 \%(\mathrm{f}=8)$ in $54 \mathrm{~kg}$. Pandedollyo technique is used only in men $72 \mathrm{~kg}$ at $2 \%(f=1)$ rate.

Table 3. The frequency and percentage values of the techniques used in the men weights in the 2017 World Championship finals

\begin{tabular}{|c|c|c|c|c|c|c|c|c|c|c|c|c|c|c|c|c|c|c|}
\hline \multirow{2}{*}{$\begin{array}{l}\text { Weights } \\
\text { Techniques }\end{array}$} & \multicolumn{2}{|c|}{$54 \mathrm{~kg}$} & \multicolumn{2}{|c|}{$58 \mathrm{~kg}$} & \multicolumn{2}{|c|}{$63 \mathrm{~kg}$} & \multicolumn{2}{|c|}{$68 \mathrm{~kg}$} & \multicolumn{2}{|c|}{$74 \mathrm{~kg}$} & \multicolumn{2}{|c|}{$80 \mathrm{~kg}$} & \multicolumn{2}{|c|}{$87 \mathrm{~kg}$} & \multicolumn{2}{|c|}{$+87 \mathrm{~kg}$} & \multicolumn{2}{|c|}{ TOTAL } \\
\hline & $\mathrm{f}$ & $\%$ & $\mathrm{f}$ & $\%$ & $\mathrm{f}$ & $\%$ & $\mathrm{f}$ & $\%$ & $\mathrm{f}$ & $\%$ & $\mathrm{f}$ & $\%$ & $\mathrm{f}$ & $\%$ & $\mathrm{f}$ & $\%$ & $\mathrm{f}$ & $\%$ \\
\hline Punch & 0 & 0 & 0 & 0 & 2 & 2 & 6 & 2 & 0 & 0 & 0 & 0 & 1 & 1 & 1 & 1 & 16 & 2 \\
\hline Palding & 189 & 74 & 91 & 80 & 66 & 52 & 129 & 69 & 52 & 36 & 25 & 6 & 59 & 51 & 58 & 38 & 669 & 55 \\
\hline Pusachagi & 0 & 0 & 0 & 0 & 0 & 0 & 0 & 0 & 0 & 0 & 2 & 2 & 0 & 0 & 0 & 0 & 2 & 0,5 \\
\hline Yopchagi & 16 & 6 & 1 & 1 & 25 & 23 & 48 & 22 & 67 & 46 & 55 & 56 & 43 & 37 & 77 & 53 & 332 & 27 \\
\hline Dollyochagi & 39 & 15 & 4 & 3 & 16 & 13 & 6 & 2 & 21 & 14 & 5 & 5 & 3 & 3 & 5 & 3 & 99 & 8 \\
\hline Neryochagi & 4 & 2 & 14 & 13 & 12 & 10 & 9 & 3 & 3 & 2 & 6 & 6 & 8 & 7 & 5 & 3 & 61 & 5 \\
\hline Dwichagi & 5 & 2 & 4 & 3 & 0 & 0 & 6 & 2 & 3 & 2 & 1 & 1 & 1 & 1 & 4 & 2 & 24 & 2 \\
\hline Pandedollyo & 1 & 1 & 0 & 0 & 0 & 0 & 0 & 0 & 0 & 0 & 1 & 1 & 0 & 0 & 0 & 0 & 2 & 0,5 \\
\hline
\end{tabular}

Table 3 indicates the percentage and frequency values of the techniques used in the men of the 2017 World Championships. According to Table 3, it is observed that athletes use palding technique with a rate of $55 \%(f=669)$. It is observed that the least used technique in 2017 is pushachagi and pandedollyo at $0.5 \%(f=2)$. In terms of weight, it is seen that palding technique is used in $54 \mathrm{~kg}(74 \%)(\mathrm{f}=189)$. If the palding technique is less, it is seen that the weight is used as \% $6(\mathrm{f}=25)$ in $80 \mathrm{~kg}$. Pushachagi technique is used only in males $80 \% 2 \%(f=2)$ and pandedollyo technique is at $1 \%(\mathrm{f}=1)$ rate in males $54 \mathrm{~kg}$ and $80 \mathrm{~kg}$.

Table 4. Percentage values of techniques used in women's weight in the 2007 World Championship finals

\begin{tabular}{lllllllllllllllllll}
\hline Weights & $47 \mathrm{~kg}$ & $51 \mathrm{~kg}$ & $55 \mathrm{~kg}$ & \multicolumn{1}{l}{$59 \mathrm{~kg}$} & \multicolumn{2}{l}{$63 \mathrm{~kg}$} & \multicolumn{2}{l}{$67 \mathrm{~kg}$} & \multicolumn{2}{l}{$72 \mathrm{~kg}$} & \multicolumn{1}{l}{$+72 \mathrm{~kg}$} & TOTAL \\
\hline Techniques & $\mathrm{f}$ & $\%$ & $\mathrm{f}$ & $\%$ & $\mathrm{f}$ & $\%$ & $\mathrm{f}$ & $\%$ & $\mathrm{f}$ & $\%$ & $\mathrm{f}$ & $\%$ & $\mathrm{f}$ & $\%$ & $\mathrm{f}$ & $\%$ & $\mathrm{f}$ & $\%$ \\
\hline Punch & 5 & 9 & 0 & 0 & 0 & 0 & 1 & 2 & 0 & 0 & 1 & 2 & 0 & 0 & 0 & 0 & 7 & 2 \\
\hline Palding & 40 & 74 & 47 & 90 & 51 & 96 & 42 & 80 & 67 & 98 & 45 & 86 & 56 & 98 & 10 & 77 & 358 & 88 \\
\hline Pusachagi & 2 & 4 & 1 & 2 & 0 & 0 & 0 & 0 & 0 & 0 & 1 & 2 & 0 & 0 & 0 & 0 & 4 & 1 \\
\hline Yopchagi & 0 & 0 & 0 & 0 & 1 & 2 & 1 & 2 & 0 & 0 & 1 & 12 & 1 & 2 & 0 & 0 & 4 & 1 \\
\hline Dollyochagi & 3 & 6 & 4 & 7 & 0 & 0 & 3 & 6 & 0 & 0 & 1 & 2 & 0 & 0 & 0 & 0 & 11 & 3 \\
\hline Neryochagi & 2 & 4 & 0 & 0 & 0 & 0 & 4 & 7 & 1 & 1 & 1 & 2 & 0 & 0 & 3 & 23 & 11 & 3 \\
\hline Dwichagi & 1 & 2 & 0 & 0 & 1 & 2 & 1 & 2 & 0 & 0 & 1 & 2 & 0 & 0 & 0 & 0 & 4 & 1 \\
\hline Pandedollyo & 1 & 2 & 0 & 0 & 0 & 0 & 0 & 0 & 0 & 0 & 1 & 2 & 0 & 0 & 0 & 0 & 2 & 1 \\
\hline
\end{tabular}


Table 4 points out the percentage and frequency values of the techniques used in the women's world championships in the 2007 World Championship finals. When Table 4 is examined, it is seen that women athletes use palding technique as $88 \%$ ( $\mathrm{f}=358)$. The least used technique is pandedollyo technique as $1 \%(\mathrm{f}=2)$. In terms of weight, it was observed that the women frequency used the most of the palding technique was $98 \%(\mathrm{f}=$ $67), 63 \mathrm{~kg}$, and $77 \%(\mathrm{f}=10)$ as $+72 \mathrm{~kg}$ women. Pandedollyo technique was used in women only 47 $\mathrm{kg}$ and $+72 \mathrm{~kg} 1 \%(\mathrm{f}=2)$.

\begin{tabular}{lcccccccccccccccccc}
\hline \multicolumn{1}{l}{ Table 5. Percentage values of techniques used in women's weight in the 2017 World Championship finals } \\
\hline Weights & $46 \mathrm{~kg}$ & $49 \mathrm{~kg}$ & $53 \mathrm{~kg}$ & \multicolumn{10}{c}{$57 \mathrm{~kg}$} & $62 \mathrm{~kg}$ & $67 \mathrm{~kg}$ & $73 \mathrm{~kg}$ & $+73 \mathrm{~kg}$ & TOTAL \\
\hline Techniques & $\mathrm{f}$ & $\%$ & $\mathrm{f}$ & $\%$ & $\mathrm{f}$ & $\%$ & $\mathrm{f}$ & $\%$ & $\mathrm{f}$ & $\%$ & $\mathrm{f}$ & $\%$ & $\mathrm{f}$ & $\%$ & $\mathrm{f}$ & $\%$ & $\mathrm{f}$ & $\%$ \\
\hline Punch & 10 & 6 & 4 & 2 & 4 & 4 & 14 & 8 & 1 & 0.5 & 2 & 2 & 4 & 3.5 & 2 & 2 & 41 & 3 \\
\hline Paldıng & 62 & 36 & 46 & 21 & 14 & 13 & 50 & 30 & 71 & 36 & 39 & 38 & 79 & 63 & 38 & 7 & 399 & 35 \\
\hline Pusachagi & 2 & 1 & 0 & 0 & 0 & 0 & 3 & 2 & 1 & 1 & 2 & 2 & 3 & 2 & 14 & 14 & 26 & 2 \\
\hline Yopchagi & 60 & 35 & 10 & 54 & 64 & 62 & 77 & 46 & 10 & 52 & 41 & 40 & 16 & 13 & 33 & 32 & 495 & 43.5 \\
& & & 0 & & & & & & 4 & & & & & & & & & \\
\hline Dollyochagi & 3 & 2 & 15 & 8 & 11 & 11 & 5 & 3 & 11 & 5 & 9 & 9 & 7 & 5 & 12 & 11 & 73 & 6 \\
\hline Neryochagi & 25 & 15 & 16 & 8 & 10 & 10 & 18 & 11 & 9 & 4 & 6 & 6 & 15 & 12 & 2 & 2 & 101 & 9 \\
\hline Dwichagi & 7 & 4 & 0 & 0 & 0 & 0 & 1 & 1 & 0 & 0 & 3 & 3 & 0 & 0 & 2 & 2 & 13 & 1 \\
\hline Pandedollyo & 1 & 0.5 & 3 & 1.5 & 0 & 0 & 0 & 0 & 0 & 0 & 0 & 0 & 0 & 0 & 0 & 0 & 4 & 0.5 \\
\hline
\end{tabular}

Table 5 shows the percentage and frequency values of the techniques used in women's weight in the 2017 World Championship finals. When Table 5 is examined, it is seen that female athletes used yopchagi technique in 2017 as maximum $43.5 \%$ ( $f=$ 495). Women athletes use pandedollyo as the least used technique $(0.5 \%$ ( $f=4)$. In terms of gears, it is seen that yopchagi technique is used at most as $052 \%(\mathrm{f}=104)$ in $62 \mathrm{~kg}$ and at least $13 \%(\mathrm{f}=16)$ in 73 $\mathrm{kg}$. The least used pandedollyo technique in women in 2017 was $\% 0.5 \%(f=1)$ in $46 \mathrm{~kg}$ and $1.5 \%(f=3)$ in $49 \mathrm{~kg}$, in other womens' weigths it was never used.

Table 6. The technique. received penalties and points of women athletes in 2007 and 2017 World Championship finals

\begin{tabular}{lccccc}
\hline$(\mathrm{n}=16)$ & 2007 & 2017 & $\overline{ \pm} \pm \mathrm{sd}$ & $\mathrm{Z}$ & $\mathrm{p}$ \\
\hline Technique & 404 & 1152 & $778.00 \pm 386.26$ & 3.411 & $\mathbf{0 . 0 0 1}^{* *}$ \\
\hline Point & 50 & 100 & $75.00 \pm 25.84$ & -3.411 & $\mathbf{0 . 0 0 1}^{* *}$ \\
\hline Penalty & 22 & 56 & $39.00 \pm 17.58$ & --3.478 & $\mathbf{0 . 0 0 1}^{*}$ \\
\hline $\mathrm{P}<0.01$ & & & &
\end{tabular}

When the Table 6 was examined the technical value of women athletes in the finals of the 2007 and 2017 world championships, and the statistical values of the penalties and points they received are seen. There was a statistically significant result found in terms of the technical numbers of women athletes in the final competitions in 2007 and 2017 ( $\bar{x} \pm$ sd $=$ $778.00 \pm 386.26 ; p<0.01)$. In 2007 and 2017, it was observed that there was a statistically significant result in the final competitions ( $\bar{x} \pm s d=75,00 \pm 25,84$; $\mathrm{p}<0,01)$. Again, it was determined that the women athletes have a statistically significant result in terms of the penalties they received in the final competitions in 2007 and 2017 ( $\bar{x} \pm \mathrm{sd}=39.00 \pm 17.58$; $\mathrm{p}<0.01$ ).

Table 7. The technique. received penalties and points of men athletes in 2007 and 2017 World Championship finals

\begin{tabular}{lccccc}
\hline$(\mathrm{n}=16)$ & 2007 & 2017 & $\mathrm{x} \pm \mathrm{sd}$ & $\mathrm{Z}$ & $\mathrm{p}$ \\
\hline Technique & 525 & 1205 & $865.00 \pm 351.15$ & -3.376 & $\mathbf{0 . 0 0 1}^{* *}$ \\
\hline Point & 47 & 141 & $94.00 \pm 48.56$ & -3.376 & $\mathbf{0 . 0 0 1}^{* *}$ \\
\hline Penalty & 32 & 39 & $35.50 \pm 3.82$ & -3.376 & $\mathbf{0 . 0 0 1}^{* *}$ \\
\hline $\mathrm{P}<0.01$ & & & & &
\end{tabular}

In the Table 7 the men athletes in the finals of the 2007 and 2017 world championships have the technical value, the penalty and the points they have received are statistically meaningful. In 2007 and 2017, there were statistically significant results in the number of male athletes in the final competition $(\bar{x} \pm s d=865.00 \pm 351.15 ; p<0.01)$. In 2007 and 2017, it 
was observed that male athletes had statistically significant results depending on their scores in the final competitions $(94,00 \pm 48,56 ; p<0,01)$. In 2007 and 2017, there was a statistically meaningful DISCUSSION \& CONCLUSION

In this study, the most recent World Championship in 2007 with the old system, manual system and the latest World Championships in 2017 with the new system, the electronic system, were examined. When the findings were examined, there were statistically significant differences between the techniques used in the competition and the techniques used in the competitions in 2017 (females; $\mathrm{p}=.001$, male; $\mathrm{p}=.001$ ). In the World Championship finals of 2007, while women athletes used a total of 404 techniques, they used a total of 1152 techniques in the 2017 world championship finals. In 2007, totally 525 techniques were used in men in 2007 and in 20171205 techniques were used.

Changing scoring systems have also created an impact on scoring variable in old and new competitions. In 2007, while women athletes received a total of 50 points in the World Championship finals, in 2017 they received a total of 100 points. When the men were examined, while a total of 47 points were achieved in the world championship final matches in 2007, totally 141 points were gained in 2017. There were statistically significant differences found between the 2007 and 2017 world championships in terms of women and men finals (women; $p=.001$, men; $p=.001$ ). The reason for this situation can be said as the increase in point values of the techniques applied to both the body and head part in today's Taekwondo.

When the findings are examined, it is seen that the World Taekwondo Championships finals in 2007 and 2017 and in the men and women in 2017 World Championships in 2017, the athletes received more penalties during the match and this situation is seen statistically meaningful. The reason of this situation is the changing rules in taekwondo are more stringent in recent years and many new rules have been introduced in order to keep the athletes more active during the match. For example, when the athlete falls to the ground in the old rules while it is not a situation that should be punished, it is a situation that is punished according to the new rules (22).

When a comparison done in terms of the techniques used, the highest number of palding techniques was used in female athletes in 2007 difference found in men in the final competition depending on penalty variable $(\overline{\mathrm{x}} \pm \mathrm{sd}=35,50 \pm 3,82 ; \mathrm{p}$ $<0,01)$.

$(88 \%)$, while the most used yopchagi technique $(43.5 \%)$ was used in 2017 . While the frequency of the neryochagi technique applied to the head area was 11, in 2017 the frequency was found as 101. While the frequency of yopchagi technique in males is 15 in 2007, it was 332 in 2017.

Similar to our study İmamoğu et al. (9), researched the technical analysis of the intercollegiate World Wrestling Championship freestyle finals. Observation form prepared before the competitions recorded by two researchers, technical analysis of the records were made. Lightweighted wrestlers won the $51.85 \%$ of the matches and lightweight athletes gained $48.15 \%$ of the matches with technique supremacy. While heavyweight athletes won $75 \%$ of the games with a score supremacy they won $25 \%$ it by technical superiority.

In a study of Dindar et al. (5) 2006 in Wimbledon tennis tournament, males were asked to determine whether the detection of the serve parts in the semi-final and final competitions and the effects of gains points in competitions. By recording the competitions on DVD (Digital Video Disc) they were slowed down while the competitions observed. According to result of the study in gaining score it was determined that most of the services fell to region 2 and 4 . This means, the areas where services are performed affect the success or failure of the service.

İmamoğlu et al. (7) held in Izmir in study $2 \mathrm{dn}$ Stars European Freestyle and Greco-Roman Wrestling Championships in performing the analysis of the male competitions to evaluate the technique values of Turkish National Team wrestlers competitions were recorded with camera and with those records the competition analyses were done. As a result of this research, it was seen that both in free and grekoromen wrestling matches in total and class matches, the way of winning matches was seen high. In this championship, totally 1951 points were obtained with 1278 techniques in 229 free wrestling competitions, with 8.51 points and 5.58 techniques per game.

In the study of Soygüden et al. (19), they analyzed technical analysis of the finals of stars free wrestling group competitions. When the victories 
are victorious, $70 \%$ of the winner, $16.6 \%$ with the pin and $10.4 \%$ with the number pin are determined. In the examinations made in the competitions, the technical ratio was found as $13 \%$ and $87 \%$ in standing techniques. In other words, the number of standing techniques was found high.

Kolukisa et al. (12) 2001 World Greco-Roman and Freestyle Wrestling Championships competition technical analysis and study that compares the technical criteria that factor in the success in the competition in Greco-Roman Wrestling Championship most whisking, suples and back into the game while applying free; only one permanent, whisk and yoke were applied. It was found that wrestlers chose to earn points without risk, and 7 points in the game and 8 points given in freestyles. They stated that it was of great importance to apply technical techniques to win the match in wrestling and not to give technical opportunity to the opponent.

Aydos et al. (1) 23th International Yaşar Doğu Freestyle Wrestling Tournament as a result of the study conducted to analyze the competition in 23 different games in the first 5 parts in the game as the sharing of suppression, flapping, single plunge and contra technique, while they create $80 \%$ of all games, total of all other techniques created the $20 \%$ of it. Depending on the applied techniques, $50 \%$ was evaluated as 1 point and $42 \%$ as 2 points.

Bridge et al. (3) in the study of the 2005 world taekwondo championship of the 3-weights of the elite male contestants were analyzed. The frequency and duration of movements were recorded as analysis. Kick numbers, combat activity, preparatory activity, unprepared activity and stop actions were also evaluated. As a result of the study, there were differences in terms of average combat duration and the number of techniques used, while lightweight had to be more active than heavy weight, whereas vice versa. It may be useful to reconsider training programs.

In the study of Tornello et al. (21), it was stated that there was no difference between rounds and matches in the matches analyzed in the Italian Taekwondo Stars Championships because the young athletes could not have certain match strategies and had limited tactical skills. Besides, it should be noted that the movements of the young taekwondo doers in the match should include various combinations of complex techniques and should include agility, speed and force skills.
Menescardi et al. (14) examined the relationship between the rounds, the results and the tactical aspects of the national inter-national taekwondo competition. The winners performed less direct and counter attack than the losers. However, they made full counterattacks in terms of more timing. In terms of round tactics, in the third round, direct and forward techniques were used more frequently than in the previous rounds. Therefore, according to the results of this study, coaches, especially in the third round, have been suggested that they should provide tactical training against various counterattacks. In this study, male and female taekwondo athletes were more likely to use pawgue shots than kicks applied to the head region. In addition, the attack kicks were used more than counter attack kicks. This result supports our study.

As a result, when the competitions between the old system and the new system are compared in Taekwondo, it can be said that the athletes use much more techniques in the new system and the points they earn during the match are highly dependent on the changing rules and technical numbers. At the same time, it was seen that the athletes increased during the match compared to the previous years. The reason for this is also thought to be caused by changing rules. Thus, it is very important that the athletes in the new system can perform accurate techniques, apply combined techniques, and develop head impact skills in order to be successful in the electronic system, which is the new system in taekwondo, in training and competitions.

\section{REFERENCES}

1. Aydos L, Koç H, Yiğitbaşı İ. XXIII. Uluslararası Yaşar Doğu serbest güreş turnuvası müsabakalarının analizi. Gazi Beden Eğitimi ve Spor Bilimleri Dergisi, 1999; 3 (1), 35-42.

2. Boutheir D, Barthed D, David B, Grehaigne JF. Tactical analysis of play combinations in rugby union with videocomputer technology - Rationalising French 'flair'. In M.D. Hughes (Ed), Notational Analysis of Sport - I E II. UWIC, Cardiff, 1996; 135-144.

3. Bridge CA, Jones MA, Drust B. The activity profile in international taekwondo competition is modulated by weight category. International journal of sports physiology and performance, 2011; 6(3), 344-357.

4. Bridge CA, Silva Santos da JF, Chaabene H, Pieter W, Franchini E. Physical and physiological profiles of taekwondo athletes. Sports Med, 2014; 44,713-733.

5. Dindar MD, Toksöz İ, Taşkın C, Uluçam E. Analysis of the serves in the men's semi-final and final competitions of wimbledon tennis tournament. e-Journal of New World Sciences Academy, 2011; 6 (3), 185-192. 
6. Işık T, Gençer RT. Basketbolda takım performansının teknik analizi: iç saha ve diş saha performanslarının değerlendirilmesi, Spor Bilimleri Dergisi, 2007; 18 (3), 101-108.

7. İmamoğlu O, Atan T, Kolukısa Ş, Kaldırımcı M, Kishalı NF. 2. Yıldızlar avrupa serbest ve greko-romen güreş şampiyonası müsabaka analizi. Atatürk Üniversitesi BESYO, Beden Eğitim ve Spor Bilimleri Dergisi, 2004; 6 (4). 29-37.

8. İmamoğlu O, Açak M, Bayram L. Taekwondo müsabaka kurallarında yapılan bazı değişikliklerin müsabakalardan kullanılan tekniklere olan etkisinin araştırılması. Journal of Sports and Performance Researches, 2010; 1 (1), 30-37.

9. İmamoğlu O, Erkin A, Mayda MH, Öztürk O, Yılmaz AK. 12th world universities wrestling championship free style competition technical analysis. European Journal of Physical Education and Sport Science, 2017; 3 (11), 181-193.

10. Kazemi M, Perri G, Soave D. A profile of 2008 olympic taekwondo competitors. J Can Chiropr Assoc, 2010; 54(4), $243-$ 249.

11. Ko YJ, Chang Y, Y Rhee YC, Valacich JS, Hur Y, Park C. Value-based stakeholder loyalty toward sport technology. A case of the electronic body protector and scoring system in taekwondo events. International Journal of Sport Science, 2014 $10(1), 46-62$.

12. Kolukısa Ş, İmamoğlu O, Ziyagil MA. Kıshalı NF.

46. dünya greko-romen ve 35 . dünya serbest güreş şampiyonası müsabaka teknik analizi karşılaştırılması, Atatürk Üniversitesi Beden Eğitimi ve Spor Bilimleri Dergisi, 2004; 6 (1), 18-29.

13. Var SM, Tuncel S, Var L. Hizlı tempo müziğin

taekwondocuların performansları üzerindeki bazı etkileri. SSTB International Refereed Academic Journal of Sports, Health $\mathcal{E}$ Medical Sciences, 2015; 17 (1), 150-167.
14. Menescardi C, Lopez-Lopez JA, Falco C, Hernandez Mendo A, Estevan I. tactical aspects of a national university taekwondo championship in relation to round and match outcome. The Journal of Strength $\mathcal{E}$ Conditioning Research, 2015; 29(2), 466-471.

15. Mirvic E, Kazazovic B, Aleksandrovic M. Differences between winning and losing teams from World water polo Championship for women. Homo Sporticus, 2011; 13 (2), 4148.

16. Müniroğlu S. Futbolda müsabaka analizi ve gözlemin önemi, 3.Ulusal Futbol ve Bilim Kongresi Bildiri Kitabı, 2009; 17.

17. Park YH, Seabourne T. Taekwondo Techniques $\mathcal{E}$ Tactics. Champaign, IL: Human Kinetics, 1997.

18. Song Y, Jeon Y, Park G, An H, Hwang T, Lee H, Lee S. Development of taekwondo trainer system for training on electronic protector with hitting target indicator. International Journal of Computer Science and Network Security, 2010; 10 (6), 51-56.

19. Soygüden A, Eker H, Toy AB, Mumcu Ö. Yıldızlar serbest güreş grup müsabakalarının teknik analizlerinin incelenmesi. Route Educational and Social Science Journal, (2014) 1(3), 186193.

20. Tel M. Taekwondo as a sport branch. Sport Sciences, 2008; 3(4), 194-202.

21. Tornello F, Capranica L, Chiodo S, Minganti C, Tessitore A. Time-motion analysis of youth olympic taekwondo combats. The Journal of Strength $\mathcal{E}$ Conditioning Research, 2014; 27(1), 223-228.

22. World Taekwondo Federation. Competition Rules \& interpretation. Available at: http://www.wtf.org/wtf_eng/site/rules/competition.html. Accessed September 122018. 